\title{
LUT
}

Lappeenranta

University of Technology

\section{Deposition of Organic and Black Carbon: Direct Measurements at Three Remote Stations in the Himalayas and Tibetan Plateau}

\author{
Yan Fangping, He Cenlin, Kang Shichang, Chen Pengfei, Hu Zhaofu, Han \\ Xiaowen, Gautam Sangita, Yan Caiqing, Zheng Mei, Sillanpää Mika, Raymond \\ Peter, Li Chaoliu
}

This is a Author's accepted manuscript (AAM) version of a publication published by John Wiley \& Sons

in Journal of Geophysical Research: Atmospheres

DOI: $10.1029 / 2019 J D 031018$

Copyright of the original publication: @2019. American Geophysical Union

Please cite the publication as follows:

Yan F., He C. Kang S., Chen P. Hu Z. Han X., Gautam S., Yan C., Zheng M., Sillanpää M., Raymond P., Li C. (2019). Deposition of Organic and Black Carbon: Direct Measurements at Three Remote Stations in the Himalayas and Tibetan Plateau. Journal of Geophysical Research: Atmospheres, Vol 124, Issue 16. p. 9702-9715. DOI: 10.1029/2019JD031018 
He Cenlin (Orcid ID: 0000-0002-7367-2815)

Kang Shichang (Orcid ID: 0000-0003-2115-9005)

Chen Pengfei (Orcid ID: 0000-0001-8591-1206)

Raymond Peter A (Orcid ID: 0000-0002-8564-7860)

Li Chaoliu (Orcid ID: 0000-0003-2092-2435)

Deposition of organic and black carbon: direct measurements at three remote stations in the Himalayas and Tibetan Plateau

\author{
Fangping Yan ${ }^{1,2,3}$, Cenlin $\mathrm{He}^{4}$, Shichang Kang, ${ }^{3,5,6}$, Pengfei Chen ${ }^{3}$, Zhaofu $\mathrm{Hu}^{3,6}$, \\ Xiaowen Han ${ }^{2,6}$, Sangita Gautam²,6, Caiqing Yan ${ }^{7}$, Mei Zheng7 ${ }^{7}$, Mika Sillanpää ${ }^{1}$ Peter \\ A. Raymond ${ }^{8}$, Chaoliu Li ${ }^{2,5}$ \\ ${ }^{1}$ Department of Green Chemistry, LUT University, Sammonkatu 12, FI-50130 Mikkeli, Finland \\ ${ }^{2}$ Key Laboratory of Tibetan Environment Changes and Land Surface Processes, Institute of Tibetan Plateau \\ Research, Chinese Academy of Sciences, Beijing 100101, China
}

${ }^{3}$ State Key Laboratory of Cryospheric Sciences, Northwest Institute of Eco-Environment and Resources,

Chinese Academy of Sciences, Lanzhou, 730000, China

${ }^{4}$ Advanced Study Program, National Center for Atmospheric Research, Boulder, CO 80301, USA

${ }^{5}$ CAS Center for Excellence in Tibetan Plateau Earth Sciences, Chinese Academy of Sciences, Beijing 100085, China

${ }^{6}$ University of Chinese Academy of Sciences, Beijing 100049, China

This article has been accepted for publication and undergone full peer review but has not been through the copyediting, typesetting, pagination and proofreading process which may lead to differences between this version and the Version of Record. Please cite this article as doi: 10.1029/2019JD031018 
${ }^{7}$ SKL-ESPC and BIC-ESAT, College of Environmental Sciences and Engineering, Peking University, Beijing 100871, China

${ }^{8}$ Yale School of Forestry and Environmental Studies, Yale University, New Haven, Connecticut 06405, USA

Corresponding author: Chaoliu Li (lichaoliu@itpcas.ac.cn)

\section{Key Points:}

- Large spatial variations in WIOC and BC deposition rates were found among three study stations due to complex local factors

- In situ $\mathrm{BC}$ dry/wet deposition rates at study station were much higher than those from the CAM5 model due to the influence of mineral dust

- Dry deposition rates of WIOC and BC were comparable or even higher than their wet deposition rates at the study stations

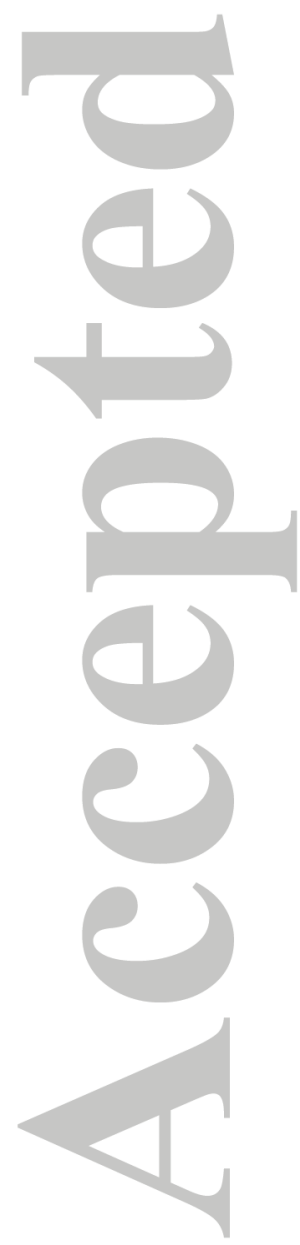




\section{Abstract}

Carbonaceous matter in the atmosphere has an important influence on climate change. Currently, the deposition of carbonaceous matter is one of the largest uncertainties in the climate system. This phenomenon is common in remote regions, such as the Himalayas and Tibetan Plateau. In this study, for the first time, we reported in situ measurements of wet and dry deposition rates of carbonaceous matter at three remote stations: Nam Co, Lulang, and Everest. The results showed that the annual wet deposition rates of water-insoluble organic carbon (WIOC) and black carbon (BC) were 60.2 and $5.8 \mathrm{mg} \mathrm{m}^{-2} \mathrm{yr}^{-1}, 330$ and $34.6 \mathrm{mg} \mathrm{m}^{-2}$ $\mathrm{yr}^{-1}$, and 47.0 and $2.6 \mathrm{mg} \mathrm{m}^{-2} \mathrm{yr}^{-1}$ at the Nam Co, Lulang, and Everest stations, respectively. Seasonal variations in the wet deposition rates of WIOC and $\mathrm{BC}$ were controlled by precipitation amount and their atmospheric concentrations. In addition, the wet scavenging ratios of WIOC and BC at Nam Co Station were close to those observed in other remote areas. The total BC deposition at Nam Co Station $\left(15.3 \mathrm{mg} \mathrm{m}^{-2} \mathrm{yr}^{-1}\right)$ was higher than that from chemical transport models, implying a dominant role of dry deposition of $\mathrm{BC}$ in the total deposition at this station and an urgent need to improve the aerosol deposition in models for the Himalayas and Tibetan Plateau. It was found that the deposition rates of carbonaceous matter in the Himalayas and Tibetan Plateau had large spatial variation; thus high-resolution models need to be applied in the future.

\section{Introduction}

Aerosols in the atmosphere contain a large portion of carbonaceous matter, which generally consists of two components: organic carbon (OC) and black carbon (BC) (Petzold et al., 2013). The former component can be further divided into water-insoluble OC (WIOC) and dissolved $\mathrm{OC}$ (DOC). $\mathrm{BC}$ is mainly derived from incomplete combustion emissions. Correspondingly, OC is produced from multiple sources, including combustion emissions, the natural release of organic matter (e.g., plant debris, pollen, spores, sea spray and soil), and the atmospheric oxidation of volatile organic compounds emitted from natural or anthropogenic processes (Seinfeld \& Pankow, 2003). Carbonaceous matter has been identified as one of the most important anthropogenic agents of climate forcing (Bond et al., 
2013; Jacobson, 2004; Ramanathan \& Carmichael, 2008). BC acts as a warming element in the atmosphere by absorbing solar radiation (Ramanathan \& Carmichael, 2008). OC exerts both cooling and warming effects on the climate (Andreae \& Gelencsér, 2006). When deposited on ice and snow surfaces, both $\mathrm{BC}$ and $\mathrm{OC}$ absorb solar radiation and reduce the albedo of snow and ice, making these components important triggers of glacier retreat (Dou \& Xiao, 2016; Kaspari et al., 2011; Li et al., 2017c; Quinn et al., 2011; Xu et al., 2009).

Despite the significance of carbonaceous matter in climate forcing and cryosphere evolution (Kang et al., 2019), there are still large uncertainties about its deposition and lifetime (Sharma et al., 2013; Wang et al., 2014; Yasunari et al., 2010; Zhang et al., 2015b). Wet deposition plays an important role in the global removal of carbonaceous matter from the atmosphere (Cerqueira et al., 2010; Dou \& Xiao, 2016; Garrett et al., 2017; Jurado et al., 2008). However, the wet deposition of carbonaceous matter is still poorly constrained worldwide, mainly due to the limited availability of in situ data (Custodio et al., 2014; Zhang et al., 2015a; Zhang et al., 2015b). Different wet scavenging ratios and lifetimes of WIOC and $\mathrm{BC}$ are applied in different models (Cooke, 2002; Textor et al., 2006). These differences are an important limitation in validating global aerosol models and simulating the concentrations and transport of carbonaceous matter in the atmosphere and in the predictions of the climate forcing of carbonaceous aerosols. Currently, several studies have evaluated the wet deposition of carbonaceous matter. For example, the wet deposition of particulate carbon has been measured at a remote marine site in the Azores (Custodio et al., 2014), a coastal site in Portugal and a continental site in Switzerland (Zhang et al., 2015a). The wet deposition of BC has been investigated by both observations and modeling in the remote Arctic (Qi et al., 2017a, 2017b; Sharma et al., 2013). However, related data are still scarce in remote regions with extreme terrain variations.

The Himalayas and Tibetan Plateau is a typical remote region, and the area has the largest glacier area in the middle latitudes. Currently, research on carbonaceous matter in the Himalayas and Tibetan Plateau has become a hotspot due to its important role in the climate system and the effect on the albedo of ice and snow in the glacier region after deposition (He 
et al., 2014a, 2014b, 2018; Kaspari et al., 2011; Qian et al., 2015; Ming et al., 2013). To date, many studies related to carbonaceous matter have been conducted in this area, with a focus on sources, concentration variations (Cong et al., 2015; Ming et al., 2008, 2009; Zhang et al., 2017; Xu et al., 2018; Cao et al., 2011; Chen et al., 2019), optical properties (Li et al., 2016c, 2017b; Wang et al., 2015; Yan et al., 2016; Niu et al., 2018), carbon isotopic compositions (Huang et al., 2010; Li et al., 2016a, 2018a) and historical profiles (Kaspari et al., 2011). Nevertheless, direct measurements of the wet and dry depositions of carbonaceous matter in this remote and sensitive region are limited. At present, except for several studies on the wet deposition of the precipitation DOC in typical urban cities and remote areas ( $\mathrm{Li}$ et al., 2017b, 2016d), only three studies have discussed the wet deposition of particulate carbon in the Himalayas and Tibetan Plateau. One study estimated the total deposition of BC at Nam Co Station and glacial regions using aerosol and snow pit samples (Li et al., 2017a), while the other two studies evaluated BC deposition in the Himalayas and Tibetan Plateau by chemical transport models (Bauer et al., 2013; Zhang et al., 2015b).

In this study, the WIOC and BC in the precipitation of three remote stations in the Himalayas and Tibetan Plateau (i.e., the Nam Co, Lulang and Everest stations) were investigated from 2015 to 2017. This study is the continuation of our previous studies on the wet deposition of precipitation DOC (Li et al., 2017b) and the total deposition of BC at Nam Co Station and glacial regions ( $\mathrm{Li}$ et al., 2017a). The primary goals of this study include (1) investigating the temporal and spatial variations in the WIOC and BC in the precipitation at three remote stations; (2) estimating the wet and dry deposition of WIOC and BC at the three stations and comparing these estimates with those from model simulations; and (3) achieving in situ wet scavenging ratios of WIOC and BC in the study area.

\section{Materials and methods}

\subsection{Sampling site}

The precipitation samples were collected at Nam Co Station (Nam Co Monitoring and

Research Station for Multisphere Interactions), Lulang Station (South-East Tibetan Plateau 
Station for integrated observation and research of alpine environments) and Everest Station (Qomolangma Station for Atmospheric and Environmental Observation and Research) from 2015 to 2017 (Figure 1, Table S1 and Text S1). The precipitation was monitored continually with automatic weather stations established at the three stations. The annual precipitation amounts were $313.2 \mathrm{~mm}, 1009.5 \mathrm{~mm}$ and $189.8 \mathrm{~mm}$ at Nam Co, Lulang and Everest stations, respectively, with a distinct wet monsoon season (Figure 2).

\subsection{Sample collection and analysis}

In total, 71, 48 and 14 precipitation samples were collected at Nam Co, Lulang and Everest stations, respectively, from 2015 to 2017 using a prebaked aluminum basin (Table S1 \& Text S1). According to the hourly precipitation amount recorded by the rain gauge, the precipitation amounts of the study samples accounted for $52 \%, 47 \%$ and $29 \%$ of the total precipitation amounts during the sampling period at Nam Co, Lulang and Everest stations, respectively. Dry deposition samples were collected monthly at Nam Co Station during the non-monsoon period (from January to May 2017 and from October to December 2017) with a stainless steel bucket; samples were pretreated following the protocols in Han et al. (2007a) (Text S1).

After filtration, the dry and wet deposition filter samples were dried at $60^{\circ} \mathrm{C}$ for 2 hours to remove water and subsequently equilibrated in a desiccator for 24 hours before weighing (Torres et al., 2013). The WIOC and BC concentrations of all samples were analyzed by the Desert Research Institute (DRI) Model 2001 thermal/optical reflectance (TOR) carbon analyzer following the IMPROVE-A protocol (Text S2; Chow \& Watson, 2002).

\subsection{Blank test and artifact}

\subsubsection{Blank test}

Four blank samples from each station were prepared by adding $200 \mathrm{~mL}$ ultrapure water to the aluminum basin, which was placed outside at the station for $2 \mathrm{~h}$ without the precipitation; these samples were then subjected to the same processes as those of the precipitation samples. The average WIOC and BC concentrations of the blank samples were 
$0.054 \pm 0.002$ and $0.0 \mu \mathrm{g} \mathrm{mL} \mathrm{m}^{-1}$, respectively, supporting the clean sampling and analysis processes. Meanwhile, three blank samples were prepared by adding $200 \mathrm{~mL}$ ultrapure water into a pre-cleaned stainless steel bucket and treated by the same processes with collected dry deposition samples. The average WIOC and BC concentrations of these blanks were $0.036 \pm 0.019$ and $0 \mu \mathrm{g} \mathrm{mL} \mathrm{m}^{-1}$, respectively, which were far lower than those of the dry deposition samples. The reported results of the samples were corrected by the blank values. New aluminum basins and new buckets were used for every sampling event during the study period to avoid any contamination.

\subsubsection{Collection efficiency}

The collection efficiency of particulate carbon could be altered by the following major aspects: the adhesion, evaporation, settling of particulate carbon to the collector and filtering efficiency. To avoid the influence of dry deposition, evaporation, and adhesion of particles and to meet the analysis requirements, samples were mainly collected during heavy precipitation. Moreover, the settling of particles was minimized by washing the basin using the supernatant of each precipitation sample during the process of transferring the sample to the bottle. To improve the filtering efficiency, a coagulant, $\mathrm{NH}_{4} \mathrm{H}_{2} \mathrm{PO}_{4}$, was added to the collected precipitation samples (Text S1; Li et al., 2016a; Torres et al., 2013). Thus, the filtering efficiency could be increased to $95 \%$ (Torres et al., 2013), resulting in a slight underestimate of the WIOC and $\mathrm{BC}$ concentrations.

\subsection{3. $\mathrm{BC}$ recovery during pretreatment and analysis}

The methods for the pretreatment and analysis of the dry deposition samples were adopted from a previous study (Han et al., 2007a). A national standard ( $n$-hexane soot) was used to test the protocols in this study, and the recoveries were $92-105 \%$, indicating that the protocols we used were reliable for separating mixtures in deposited materials (Han et al., 2007b). Meanwhile, the sucrose solution was measured with the samples to ensure a stable condition of the instrument and the IMPROVE-A protocol during analysis. The concentration 
deviation of sucrose solution was within $5 \%$, suggesting that the analytical method was credible and repeatable.

\subsection{Wet and dry deposition rates of WIOC and BC}

The annual wet deposition rates of the WIOC and $\mathrm{BC}$ in the precipitation were calculated using the volume-weighted mean concentrations of WIOC and BC and the average annual precipitation amount at each station because not every precipitation event was sampled at the study stations. The wet deposition rate was calculated based on the following equations:

$$
\begin{aligned}
& \mathrm{Fc}=\mathrm{Ci} \times \mathrm{Pi} \\
& \mathrm{Ci}=\frac{\sum_{j=1}^{j=n} C j \times P j}{\sum_{\substack{j=1 \\
j=n}}^{j=n}}
\end{aligned}
$$

where $\mathrm{Fc}\left(\mathrm{g} \mathrm{C} \mathrm{m}^{-2} \mathrm{yr}^{-1}\right)$ expresses the WIOC or BC wet deposition rate, $\mathrm{C}_{\mathrm{i}}\left(\mathrm{mg} \mathrm{L}^{-1}\right)$ represents the volume-weighted mean concentrations of WIOC or BC in the precipitation at station $\mathrm{i}, \mathrm{Cj}$ $\left(\mathrm{mg} \mathrm{L}^{-1}\right)$ stands for the concentration of WIOC or BC in individual precipitation sample $\mathrm{j}, \mathrm{Pi}$

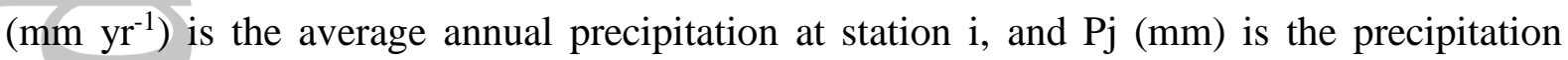
amount corresponding to the precipitation sample $\mathrm{j}$.

The dry deposition rates at Nam Co Station were calculated based on the concentrations of WIOC and BC of the collected dry deposition sample. The dry deposition rates at Lulang and Everest stations were calculated using the method from Fang et al. (2015). The total deposition rate was calculated by summing dry and wet deposition rates throughout the year.

\subsection{Calculation of wet scavenging ratios}

The scavenging ratio is commonly used to quantify the tendency of the removal of a species or component from the atmosphere by precipitation (Cerqueira et al., 2010). This ratio is defined as the ratio of the concentration of a species in the precipitation to the concentration of the species in the atmosphere and can be calculated according to the following equation (Ducret \& Cachier, 1992):

$$
S=\frac{[X]_{\text {precipitation }}}{[X]_{\text {atmosphere }}}
$$


where $[X]_{\text {precipitation }}$ and $[X]_{\text {atmosphere }}$ are the concentrations of a species in the precipitation $\left(\mu \mathrm{g} \mathrm{L}^{-1}\right.$ (water)) and atmosphere $\left(\mu \mathrm{g} \mathrm{m} \mathrm{m}^{-3}\right.$ (air)), respectively.

\section{Results and discussion}

\subsection{WIOC and $B C$ concentrations in precipitation}

After removing of the potential influence of carbonate carbon on the concentrations of WIOC and BC (Figure S1; Text S3; Chow et al., 1993), the volume-weighted mean concentrations of WIOC and BC were $192 \pm 234$ and $18.5 \pm 30.4,327 \pm 263$ and $34.3 \pm 41.7$, and $248 \pm 197$ and $13.5 \pm 22.9 \mu \mathrm{g} \mathrm{L}^{-1}$ at Nam Co, Lulang and Everest stations, respectively. It was expected that these values at the three sites would be lower than those located in urban cities, such as Paris, France and Tokyo, Japan (657 to $851 \mu \mathrm{g} \mathrm{L}-1$ for WIOC, 78.9 to $333 \mu \mathrm{g} \mathrm{L}^{-1}$ for BC; Ducret \& Cachier, 1992; Huo et al., 2016), but comparable with those at remote and mountainous sites (145 to $274 \mu \mathrm{g} \mathrm{L}^{-1}$ for WIOC and 5.2 to $26 \mu \mathrm{g} \mathrm{L} \mathrm{L}^{-1}$ for BC; Cerqueira et al., 2010; Huo et al., 2016) due to the clean atmosphere over the study stations (Table 1). However, the volume-weighted mean concentrations of WIOC and $\mathrm{BC}$ at the Lulang and Everest stations were higher than those observed at the adjacent glaciers of Demula and East Rongbuk. Correspondingly, the volume-weighted mean WIOC and BC concentrations of Nam Co Station were lower than those at the Zhadang glacier (Table 1). The high WIOC and BC concentrations of the Zhadang glacier were mainly attributed to two reasons. First, the pollutants originating from nearby Lhasa city reached the Zhadang glacier first, so that the influence on Nam Co was relatively weak. Second, the strong melting of the snow pit in the Zhadang glacier caused the enrichment of WIOC and BC resulting in their high concentrations. The above phenomena have been presented in previous studies (Huang et al., 2013; Ming et al., 2013). The BC concentration in the precipitation at Nam Co Station in this study was approximately 2.3 times higher than the average value of $8 \pm 7 \mu g \mathrm{~L}^{-1}$ reported in a previous study (Ming et al., 2010). This difference might be first because the precipitation samples in the previous study were limited $(\mathrm{N}=11)$ and were mainly collected during the monsoon period when the atmospheric $\mathrm{BC}$ concentration was low; second, the difference 
may be because the use of $\mathrm{NH}_{4} \mathrm{H}_{2} \mathrm{PO}_{4}$ in this study improved the $\mathrm{BC}$ collection efficiency of the precipitation samples ( $\mathrm{Li}$ et al., 2016a; Torres et al., 2013).

The relative ratios of $\mathrm{WIOC}$, DOC and $\mathrm{BC}$ can provide some insights into the sources and removal of atmospheric carbonaceous matter (Custodio et al., 2014; Huo et al., 2016). The relative contributions of $\mathrm{BC}$, WIOC and DOC in the aerosol, precipitation and snow pit samples of the three stations are shown in Figure 3. It is obvious that $\mathrm{BC}$ accounts for the smallest fraction of carbonaceous matter in the precipitation at the three study stations. The average WIOC/DOC ratio of the precipitation at the three stations was 0.29 , which was comparable to that of remote and rural sites in Japan (0.24 at Sado and 0.33 at Niigata; Huo et al., 2016) and rural sites in Europe (0.27 at K-Puszta, Hungary and 0.22 at Aveiro, Portugal; Cerqueira et al., 2010). However, this value was lower than that in an urban city (0.46 in Tokyo; Huo et al., 2016), which was probably because the carbonaceous matter in the urban city was primarily influenced by local emissions, while the carbonaceous matter in the Himalayas and Tibetan Plateau was affected by both local emissions and long-range transport pollutants from severely polluted South Asia (Li et al., 2016a, 2018a, and 2018b). During transport, the carbonaceous matter becomes aged and hydrophilic with the conversion from WIOC to DOC, resulting in a relatively low WIOC/DOC ratio. Overall, the higher WIOC to $\mathrm{BC}$ ratios in the precipitation samples than in those in the aerosol samples at the three study stations (Figure S2) indicate that WIOC is more hydrophilic and much easier to remove by precipitation than BC. Compared to nearby snow pit samples, the most obvious characteristic of the precipitation samples was the low fraction of WIOC (Figure 3), which may have been be due to the additional contributions from the dry deposition of mineral dust to glacier regions in winter.

1. (Ming et al., 2010); 2. (Li et al., 2016a); 3. (Li et al., 2016b); 4. (Huo et al., 2016); 5. (Ducret and Cachier, 1992$)$; 6. (Cerqueira et al., 2010$)$; 7. (Cadle \& Dasch, 1988). Note: The units of concentrations in scavenging ratio calculation are ( $\mu \mathrm{g} \mathrm{L}^{-1}$ (water)) for precipitation and ( $\mu \mathrm{g} \mathrm{m}^{-3}$ (air)) for the atmosphere. 


\subsection{Deposition mechanisms and rates of WIOC and BC}

\subsubsection{Dry and wet deposition mechanisms}

The dry deposition rate is mainly controlled by metrological factors (e.g., wind speed, temperature lapse rate) and the vertical distribution of the particles (Ogren, 1982). Brownian diffusion and gravitational settling within a few centimeters of the surface are the most efficient mechanisms for particle transport through the near-surface layer (Ogren, 1982). Deposition velocities are also influenced by the surface nature to which particles deposit via affecting the micrometeorological environment near the surface and the retention efficiency of the particles. Thus, it is quite difficult to obtain the real deposition velocity. In this study, we estimated the WIOC and BC deposition amounts by measuring the WIOC and BC concentrations in monthly collected dry deposition samples.

Wet deposition mechanisms of incorporating particulate carbon in precipitation can be classified into two categories: rainout process, where particles act as nucleating agents in cloud droplets or ice crystal formation, and washout process, where particles collide with the existing droplet or crystal. Generally, washout and rainout processes are both incorporated in a precipitation event, as presented by Ishikawa et al. (1995). The washout process is important at the beginning of a precipitation event, while the rainout process is more important from the middle to the end of the precipitation event. A reverse relationship has typically existed between the precipitation amount and concentration in many previous study areas, which has been partly ascribed to the effect of the washout process of particulate aerosol (Prado-Fiedler, 1990). However, this pattern was not obseved in the current study (Figure 4). Although it is difficult to determine the dominant mechanism in the scavenge process at the three study stations, this type of relationship should be a general phenomenon in the remote Himalayas and Tibetan Plateau because of the low particle concentrations in the atmosphere. The frequently used parameter to study wet deposition in modeling and flux calculation is the scavenging ratio (Fang et al., 2015; Sandnes, 1993), which conceals the complexities of the process involved and the occurring mechanisms (Harrison and Allen, 
1991). Although it cannot explicitly account for the aforementioned properties, it does provide a method to approximately evaluate the ranges of the wet deposition rates.

\subsubsection{Scavenging ratios of $\mathrm{WIOC}$ and $\mathrm{BC}$}

The scavenging ratios of WIOC $\left(0.42 \times 10^{6}, 0.08 \times 10^{6}\right.$ and $0.22 \times 10^{6}$, respectively) were higher than those of $\mathrm{BC}\left(0.24 \times 10^{6}, 0.06 \times 10^{6}\right.$ and $0.09 \times 10^{6}$, respectively) at the three study stations, indicating that WIOC was more hydrophilic than $\mathrm{BC}$; thus the WIOC could preferentially be scavenged by precipitation. This result has been reported in a number of previous studies. For example, the mean scavenging ratios of WIOC and BC were $1.24 \times 10^{6}$ and $0.08 \times 10^{6}$, respectively, at a remote site in Japan (Huo et al., 2016). The scavenging ratios of European background sites were $0.06 \times 10^{6}-0.63 \times 10^{6}$ and $0.02 \times 10^{6}-0.18 \times 10^{6}$ for WIOC and BC, respectively (Cerqueira et al., 2010) (Table 1). The large spatial variations in the WIOC and BC scavenging ratios have a noticeable implication in modeling their atmospheric concentrations. For example, it was estimated that a 3.5-fold increase in the wet scavenging ratio would cause the modeled $\mathrm{BC}$ concentrations to decrease by $30-40 \%$ in the remote regions of Scandinavia (Tsyro et al., 2007).

Due to the calculation assumption of uniform atmospheric aerosols, the high scavenging ratios of $\mathrm{BC}$ are expected at high mountains with a low vertical gradient of atmospheric aerosol concentrations (Cerqueira et al., 2010). The BC scavenging ratios at Nam Co Station were consistent with this expectation. The high BC scavenging ratios at this station could also be explained by the aging of aerosols during the long-range transport from South Asia (Lüthi et al., 2015; Li et al., 2016a; Yang et al., 2018). The scavenging ratios for both WIOC and $\mathrm{BC}$ at the Lulang and Everest stations were relatively low compared to those at Nam Co Station because the atmospheric concentrations of WIOC and BC at the former two stations were much higher than those at Nam Co Station (Table S2) due to the large influence of local emissions (Chen et al., 2018; Li et al., 2018; Wang et al., 2018). In contrast, the concentrations of WIOC and $\mathrm{BC}$ in precipitation at these two stations were slightly higher

than or comparable to those at Nam Co Station (Table 1). It is acknowledged that this approach has some limitations and uncertainties of this approach. First, most scavenging 
ratios were estimated from near-surface atmospheric concentrations, which may be quite different from those at the precipitation cloud altitude and cloud formation sites. Second, the atmospheric concentrations of $\mathrm{WIOC}$ and $\mathrm{BC}$ at the Lulang and Everest stations were adopted from other studies that were not conducted in the same period as that of the precipitation (Cong et al., 2015; Zhao et al., 2013). However, the uncertainty was minor because the annual particle variations at Lulang and Everest stations were small (Liu et al., 2017).

\subsubsection{Deposition rates of WIOC and BC}

The annual wet deposition rates of WIOC and BC at Nam Co Station during the study period were 60.2 and $5.8 \mathrm{mg} \mathrm{m}^{-2} \mathrm{yr}^{-1}$, respectively, which were between those at Lulang and Everest stations (Table 2). The largest wet deposition rates at Lulang Station were caused by multiple reasons, e.g., Lulang Station had the largest annual precipitation amount, and pollutants emitted from seriously polluted South Asia could be easily transported to this station through the Yarlung Zangbo Grand Canyon with penetrating moisture (Zhao et al., 2013). This phenomenon has also been reported by research studies on major ions and DOC of precipitation at Lulang Station (Li et al., 2017b; Liu et al., 2013). Recently, a study on atmospheric BC sources further found that emissions from local residential activities and vehicles primarily contributed to BC at Lulang Station (Wang et al., 2018). Therefore, we propose that local emissions may account for a large part of the WIOC and BC wet deposition rates at this station. This pattern also explains why Lulang Station had the highest atmospheric WIOC and BC concentrations among the three stations (Table S2), despite having the largest precipitation amount (Table. S1). Consequently, the total deposition rate of BC at Lulang Station (58.9 $\mathrm{mg} \mathrm{m}^{-2} \mathrm{yr}^{-1}$ ) was approximately 4-fold and 2-fold higher than that observed at Nam Co Station and that simulated by model in the southeastern Himalayas and Tibetan Plateau (Zhang et al., 2015b), respectively. This result is also in good agreement with the higher surface BC concentrations from in situ observations than those from the model

conducted at Lulang Station (Zhang et al., 2015b), implying that the model used by Zhang et al. (2015b) mainly underestimated the BC concentrations and total deposition at Lulang 
Station because of the large contribution of local combustion emissions. Among the three stations, Everest Station had the lowest WIOC and BC wet deposition rates, which could be attributed to the sparse precipitation amount.

Variations in the $\mathrm{WIOC}$ and $\mathrm{BC}$ deposition rates combined with the precipitation amounts can indicate the potential sources of WIOC and BC. For instance, although the heaviest precipitation occurred in August, the deposition rates of WIOC and BC in this month were lower than those in July and September at Nam Co Station (Figure 5), indicating the washout and dilution effect of long-range transport pollutants before reaching the remote Nam Co Station due to the relatively large amount of precipitation in the monsoon season. The largest WIOC and BC wet deposition rate at Lulang Station occurred in April, the pre-monsoon period, which was also a heavily polluted period in South Asia (Bonasoni et al., 2010). Thus, the WIOC and $\mathrm{BC}$ wet deposition rates were influenced by both the precipitation amount and their atmospheric concentrations at the three stations (Figure 5).

The wet deposition rates of WIOC and BC at the three study stations were lower than or comparable to those of other regions in the world. For example, the wet deposition rates of WIOC $\left(60.2,330\right.$, and $47 \mathrm{mg} \mathrm{m}^{-2} \mathrm{yr}^{-1}$, respectively, for Nam Co, Lulang and Everest stations) and $\mathrm{BC}\left(5.8,34.6\right.$, and $2.6 \mathrm{mg} \mathrm{m}^{-2} \mathrm{yr}^{-1}$, respectively) at the three stations were lower than those at Tokyo, an urban site (676 and $59.8 \mathrm{mg} \mathrm{m}^{-2} \mathrm{yr}^{-1}$; Huo et al., 2016). Meanwhile, the wet deposition rates of WIOC and BC at Nam Co Station were comparable to those at Aveiro, a rural city (61 and $7.5 \mathrm{mg} \mathrm{m}^{-2} \mathrm{yr}^{-1}$; Cerqueira et al., 2010). The wet deposition rates at Lulang Station were comparable to those at a remote site in Asia (314 and $26.3 \mathrm{mg} \mathrm{m}^{-2} \mathrm{yr}^{-1}$; Huo et al., 2016) and a mountainous site in Europe (378 and $38 \mathrm{mg} \mathrm{m}^{-2} \mathrm{yr}^{-1}$; Cerqueira et al., 2010) (Table 2). The total BC deposition rate of Nam Co Station was within the range of 6$26 \mathrm{mg} \mathrm{m}^{-2} \mathrm{yr}^{-1}$ observed in Svalbard, an Arctic site (Ruppel et al., 2014), but much lower than that of the nearby Nam Co Lake core (260 mg m $\mathrm{yr}^{-1}$; Cong et al., 2013) because the lake cores are mainly composed of sediment from the lake basin and addition to atmospheric deposition (Li et al., 2017a). 
Regarding the nearby glaciers, the total deposition rate of BC at Nam Co Station (15.3 $\mathrm{mg} \mathrm{m} \mathrm{mr}^{-1}$ ) was comparable to that of the Zhadang glacier (20.0 $\mathrm{mg} \mathrm{m}^{-2} \mathrm{yr}^{-1}$ ) (Table 2). However, the total deposition rate of WIOC at this station $\left(329.2 \mathrm{mg} \mathrm{m}^{-2} \mathrm{yr}^{-1}\right.$ ) was approximately 2 times higher than that of the Zhadang glacier $\left(153 \mathrm{mg} \mathrm{m}^{-2} \mathrm{yr}^{-1}\right)$, mainly because this station is located at a relatively lower altitude than the glacier and experiences lighter precipitation; thus, mineral dust sourced from the Himalayas and Tibetan Plateau made relatively large contributions to the dry deposition rate of particulate carbon, especially during the nonmonsoon period (Liu et al., 2017). Correspondingly, Lulang Station and its nearby glacier, Demula Glacier, are located in the forest regions of the Southeast Himalayas and Tibetan Plateau, with heavy precipitation (Lulang Station: $1010 \mathrm{~mm}$; Demula Glacier: $842 \mathrm{~mm}$ (Li et al., 2016b)), and only a few dust storms occur every year. Therefore, the dry deposition rates of WIOC and BC at Lulang Station are not as large as the rates of wet deposition (Table 2).

\subsection{Comparison between in situ and CAM5 model-derived BC deposition rates at Nam Co Station}

It is obvious that the dry deposition rates of WIOC and BC account for a large part of the total deposition rates at Nam Co Station, especially during the nonmonsoon period when precipitation is sparse (Figure 6). For example, the average ratio of the $\mathrm{BC}$ dry/wet deposition rate at Nam Co Station was 1.6, which was far higher than that estimated by the Community Atmosphere Model version 5 (CAM5, 0.1). Meanwhile, the BC dry, wet and total deposition rates at Nam Co Station in this study were approximately $11,0.7$ and 1.7 times the results from the CAM5 model (Zhang et al., 2015b), respectively, which suggested that CAM5 probably overestimated the wet deposition rate and underestimated the dry deposition rate. These different results were attributed to a number of reasons. First, the model represents the mean concentrations in the grid box and at the grid-mean elevation $\left(1.9^{\circ} \times 2.5^{\circ}\right)$ (Zhang et al., 2015b), which is different from our in situ data based on one given site. Second, the model was based on data from 2001, while our study was conducted from 2015 to 2017. Third, although the model considered internal mixing between $\mathrm{BC}$ and fine-mode dust, it did not include $\mathrm{BC}$ from 
mineral dust of the Himalayas and Tibetan Plateau; rather, only BC from combustion emissions was considered (Zhang et al., 2015b), which we think was the most important reason for the underestimation of dry deposition.

The importance of mineral dust to the carbonaceous matter of the Himalayas and Tibetan Plateau has been proven by previous studies (Kang et al., 2016; Li et al., 2009; Liu et al., 2017; Cao et al., 2009). Due to inertness, BC is widely distributed in soil dust (mineral dust). For instance, the BC concentrations in surface soil in the northern part of the Himalayas and Tibetan Plateau were $1.3 \mathrm{mg} \mathrm{g}^{-1}$ (Zhan et al., 2015); thus, soil dust can be an important contributor of BC in aerosols. This contribution widely exists in the Himalayas and Tibetan Plateau, especially in pre-monsoon season when dust storms occur (Li et al., 2017a). During this period, the particle size of aerosols increases dramatically due to the contribution of mineral dust from surface soil (Cong et al., 2009). Meanwhile, the dry deposition velocity increases rapidly with the increasing particle size for particles larger than $2 \mu \mathrm{m}$ (Zhang et al., 2001). For example, when the particle size is $3.8 \mu \mathrm{m}$, the dry deposition velocity can be up to $3.0 \mathrm{~cm} \mathrm{~s}^{-1}$, which is much higher than the constant $\left(0.15 \mathrm{~cm} \mathrm{~s}^{-1}\right)$ used in a previous study (Fang et al., 2015). Moreover, the modal size of the volume-size distribution in the Himalayas and Tibetan Plateau is $39.8-48.3 \mu \mathrm{m}$ for local mineral dust and 11.5-13.4 $\mu \mathrm{m}$ for long-range transport eolian dust (Dong et al., 2016). This evidence suggests that the dry deposition velocity in the Himalayas and Tibetan Plateau could be larger than that which has been generally anticipated. Nevertheless, we think the in situ results we reported are closer to the actual values and serve as reference data for other related studies, especially for those of Nam Co Station with sparse local sources. Another issue needs to be noted is that, although no in situ dry deposition data are available for Everest Station, it is proposed that dry deposition accounts for a higher ratio at this station than that at Nam Co Station due to the light precipitation at Everest Station (Figure S3), which can also be inferred from the fact that Everest Station has higher levels of locally sourced fine particles than those of Nam Co Station (Liu et al., 2017).

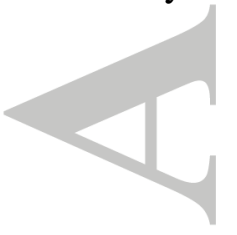


1. (Li et al., 2016a); 2. (Li et al., 2016b); 3. (Cong et al., 2013); 4. (Han et al., 2015); 5. (Bisiaux et al., 2012); 6. (Ruppel et al., 2014); 7. (Huo et al., 2016); 8. (Cerqueira et al., 2010).

\section{Conclusions and implications}

Although there were some limitations, e.g., not every precipitation event was sampled, and the dry deposition sampling at Nam Co Station covered only the non-monsoon period, the results reported in this study can serve as reference values for model research in the future. The wet deposition rates of WIOC and BC at Lulang Station were the highest among the three stations because of the heavy precipitation and high atmospheric concentrations of carbonaceous particles. The deposition data of WIOC and BC reported in this study are more reliable and closer to the "actual" values than those of previous work based on the CAM5 model. The scavenging ratios of the Lulang and Everest stations were lower than those of Nam Co Station, suggesting the influences of important local emissions (e.g. those from local residents, vehicles and mineral dust) on the high concentration of atmospheric carbonaceous matter.

The in situ measured dry deposition rates of WIOC and BC at Nam Co Station were 269 and $9.5 \mathrm{mg} \mathrm{m}^{-2} \mathrm{yr}^{-1}$, respectively, during nonmonsoon season, approximately 4.5 and 1.6 times the wet deposition rates due to the locally sourced mineral dust. This result emphasizes the importance of dry deposition at the Himalayas and Tibetan Plateau (especially during the non-monsoon season), which has been greatly underestimated by previous modeling studies, and this is an area of research that needs to be improved in the future. Similarly, the estimated high dry WIOC and $\mathrm{BC}$ deposition rates at the Everest Station suggested the importance of dry deposition contributions to the total carbon deposition. Therefore, contrast to the results of the models, this study suggests that the dry deposition rates of both WIOC and BC in the Himalayas and Tibetan Plateau (especially in the northern and western parts) are as important as or even higher than the wet deposition rates of WIOC and BC. Furthermore, the results of this study provide important implications for evaluating and improving the modeling of deposition of carbonaceous aerosols in the Himalayas and Tibetan Plateau, as both the precipitation and atmosphere deposition rates in the models are subjected to large uncertainties (e.g., He et al., 2014a; Zhang et al., 2015b). 


\section{Acknowledgements}

This study is supported by the Strategic Priority Research Program of Chinese Academy of Sciences (CAS), Pan-Third Pole Environment Study for a Green Silk Road (Pan-TPE) (XDA20040501), the NSFC $(41675130,41630754,41705132)$, the State Key Laboratory of Cryospheric Science (SKLCS-ZZ-2017), and the China Postdoctoral Science Foundation (2016M602897). Cenlin He was supported by the Advanced Study Program (ASP) Fellowship at the National Center for Atmospheric Research. The National Center for Atmospheric Research is sponsored by the National Science Foundation. This study is part of a framework across the HTP: Atmospheric Pollution and Cryospheric Change (APCC). The data presented in this study are deposited at: https://github.com/EarthSciCode/AeroDepoHTP.git. The authors acknowledge the Nam Co, Lulang and Everest stations for providing the precipitation data and sample collection. The authors are grateful to the anonymous reviewers and editor for their valuable comments which have greatly improved this work.

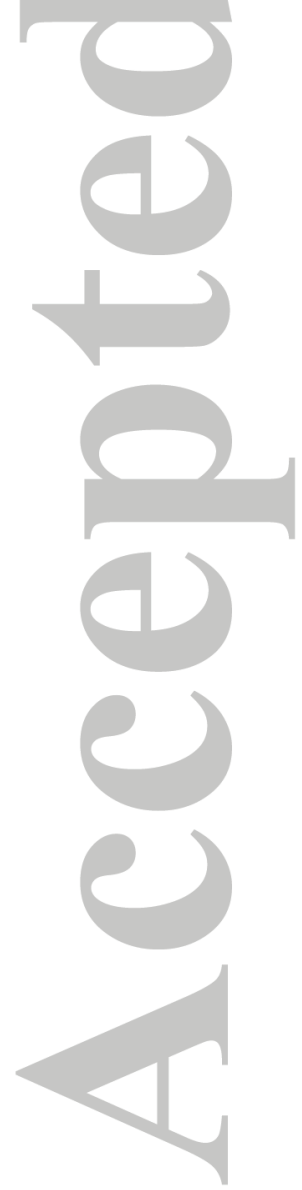




\section{References}

Andreae, M., \& Gelencsér, A. (2006), Black carbon or brown carbon? The nature of light-absorbing carbonaceous aerosols, Atmospheric Chemistry and Physics, 6(10), 3131-3148

Bauer, S. E., Bausch, A., Nazarenko, L., Tsigaridis, K., Xu, B., Edwards, R., et al. (2013), Historical and future black carbon deposition on the three ice caps: Ice core measurements and model simulations from 1850 to 2100, Journal of Geophysical Research: Atmospheres, 118(14), 7948-7961, doi:10.1002/jgrd.50612

Bisiaux, M. M., Edwards, R., McConnell, J. R., Curran, M. A. J., Van Ommen, T. D., Smith, A. M., et al. T. A. Neumann, D. R. Pasteris, J. E. Penner, and K. Taylor (2012), Changes in black carbon deposition to Antarctica from two high-resolution ice core records, 1850-2000 AD, Atmospheric Chemistry and Physics, 12(9), 4107-4115, doi:10.5194/acp-12-4107-2012

Bonasoni, P., Laj, P., Marinoni, A., Sprenger, M., Angelini, F., Arduini, J., Bonafè, U., Calzolari, F., Colombo, T., Decesari, S., 2010. Atmospheric Brown Clouds in the Himalayas: first two years of continuous observations at the Nepal Climate Observatory-Pyramid (5079 m). Atmospheric Chemistry and Physics 10, 7515-7531.

Bond, T. C., et al. (2013), Bounding the role of black carbon in the climate system: A scientific assessment, Journal of Geophysical Research: Atmospheres, 118(11), 5380-5552, doi:10.1002 /jgrd.50171

Cadle, S. H., \& J. M. Dasch (1988), Wintertime concentrations and sinks of atmospheric particulate carbon at a rural location in northern Michigan, Atmospheric Environment (1967), 22(7), 1373-1381

Cao, J. J., Xu, B. Q., He, J.Q., Liu, X. Q., Han, Y. M., Wang, G., et al. (2009), Concentrations, seasonal variations, and transport of carbonaceous aerosols at a remote Mountainous region in western China, Atmospheric Environment, 43(29), 4444-4452, doi:10.1016/j.atmosenv.2009. 06.023

Cao, J., Tie, X., Xu, B., Zhao, Z., Zhu, C., Li, G., \& S. Liu (2011), Measuring and modeling black carbon (BC) contamination in the SE Tibetan Plateau, Journal of Atmospheric Chemistry, 67(1), 45-60, doi:10.1007/s10874-011-9202-5

Cerqueira, M., Pio, C., Legrand, M., Puxbaum, H., Kasper-Giebl, A., Afonso, J., et al. (2010), Particulate carbon in precipitation at European background sites, Journal of Aerosol Science, 41(1), 51-61, doi:10.1016/j.jaerosci.2009.08.002

Chen, P., Kang, S., Li, C., Zhang, Q., Guo, J., Tripathee, L., Zhang, Y., et al. (2019). Carbonaceous aerosol characteristics on the Third Pole: A primary study based on the Atmospheric Pollution and Cryospheric Change (APCC) network, Environmental Pollution, doi: https://doi.org/10.1016/j.envpol.2019.06.112

Chen, X., Kang, S., Cong, Z., Yang, J., \& Ma, Y. (2018), Concentration, temporal variation, and sources of black carbon in the Mt. Everest region retrieved by real-time observation and simulation, Atmospheric Chemistry and Physics, 18(17), 12859-12875, doi:10.5194/acp-18$12859-2018$

Chow, J. C., \& Watson, J. G. (2002), $\mathrm{PM}_{2.5}$ carbonate concentrations at regionally representative Interagency Monitoring of Protected Visual Environment sites, Journal of Geophysical Research: Atmospheres, 107(D21), ICC 6-1-ICC 6-9, doi:10.1029/2001jd000574 
Chow, J. C., Watson, J. G., Pritchett, L. C., Pierson, W. R., Frazier, C. A., \& Purcell, R. G. (1993), The DRI thermal/optical reflectance carbon analysis system: description, evaluation and applications in US air quality studies, Atmospheric Environment. Part A. General Topics, 27(8), $1185-1201$

Cong, Z., Kang, S., Gao, S., Zhang, Y., Li, Q., \& Kawamura, K. (2013), Historical trends of atmospheric black carbon on Tibetan Plateau as reconstructed from a 150-year lake sediment record, Environment Science \& Technolpogy, 47(6), 2579-2586, doi:10.1021/es3048202

Cong, Z., Kang, S., Kawamura, K., Liu, B., Wan, X., Wang, Z., et al. (2015), Carbonaceous aerosols on the south edge of the Tibetan Plateau: concentrations, seasonality and sources, Atmospheric Chemistry and Physics, 15, 1573-1584, 2015, doi:10.5194/acp-15- 1573-2015

Cong, Z., Kang, S., Smirnov, A., Holben, B. (2009), Aerosol optical properties at Nam Co, a remote site in central Tibetan Plateau. Atmospheric Research, 92, 42-48

Cooke, W. F. (2002), A general circulation model study of the global carbonaceous aerosol distribution, Journal of Geophysical Research, 107(D16), doi:10.1029/2001jd001274

Custodio, D., Cerqueira, M., Fialho, P., Nunes, T., Pio, C., \& Henriques, D. (2014), Wet deposition of particulate carbon to the Central North Atlantic Ocean, The Science of the total environment, 496, 92-99, doi:10.1016/j.scitotenv.2014.06.103

Dong, Z., Kang, S., Qin, D., Li, Y., Wang, X., Ren, J., et al., (2016), Provenance of cryoconite deposited on the glaciers of the Tibetan Plateau: New insights from Nd-Sr isotopic composition and size distribution. Journal of Geophysical Research: Atmospheres, 121, 7371-7382

Dou, T. F., \& Xiao, C. D. (2016), An overview of black carbon deposition and its radiative forcing over the Arctic, Advances in Climate Change Research, 7(3), 115-122, doi:10.1016/j.accre. 2016.10.003

Ducret, J., \& Cachier, H. (1992), Particulate carbon content in rain at various temperate and tropical locations, Journal of Atmospheric Chemistry, 15(1), 55-67, doi:10.1007/bf00053609

Fang, Y., Chen, Y., Tian, C., Lin, T., Hu, L., Huang, G., et al. (2015), Flux and budget of BC in the continental shelf seas adjacent to Chinese high BC emission source regions, Global Biogeochemical Cycles, 29(7), 957-972, doi:10.1002/2014gb004985

Garrett, T., Zhao, C., \& Novelli, P. (2017), Assessing the relative contributions of transport efficiency and scavenging to seasonal variability in Arctic aerosol, Tellus B: Chemical and Physical Meteorology, 62(3), 190-196, doi:10.1111/j.1600-0889.2010.00453.x

Han, Y. M., et al. (2015), Elemental carbon and polycyclic aromatic compounds in a 150-year sediment core from Lake Qinghai, Tibetan Plateau, China: influence of regional and local sources and transport pathways, Environmental Science \& Technology, 49(7), 4176-4183, doi:10.1021/es 504568m

Han, Y., J. Cao, Z. An, J. C. Chow, J. G. Watson, Z. Jin, K. Fung, and S. Liu (2007a), Evaluation of the thermal/optical reflectance method for quantification of elemental carbon in sediments, Chemosphere, 69(4), 526-533, doi:10.1016/j.chemosphere.2007.03.035.

Han, Y., J. Cao, J. C. Chow, J. G. Watson, Z. An, Z. Jin, K. Fung, and S. Liu (2007b), Evaluation of the thermal/optical reflectance method for discrimination between char-and soot-EC, Chemosphere, 69(4), 569-574. 
Harrison, R. M., \& Allen, A. G. (1991). Scavenging ratios and deposition of sulphur, nitrogen and chlorine species in eastern England. Atmospheric Environment. Part A. General Topics 25, 1719-1723.

He, C., Flanner, M. G., Chen, F., Barlage, M., Liou, K. N., Kang, S., et al. (2018), Black carbon-induced snow albedo reduction over the Tibetan Plateau: uncertainties from snow grain shape and aerosol-snow mixing state based on an updated SNICAR model, Atmospheric Chemistry and Physics, 18(15), 11507-11527, doi:10.5194/acp-18-11507-2018He, C., Li, Q., Liou, K. N., Takano, Y., Gu, Y., Qi, L., et al. (2014b), Black carbon radiative forcing over the Tibetan Plateau, Geophysical Research Letters, 41(22), 7806-7813

He, C., Li, Q.., Liou, K. N., Zhang, J., Qi, L., Mao, Y., et al. (2014a), A global 3-D CTM evaluation of black carbon in the Tibetan Plateau, Atmospheric Chemistry and Physics, 14, 7091-7112, doi:10.5194/acp-14-7091-2014.

Huang, J., Kang, S., Shen, C.,. Cong, Z, Liu, K., Wang, W., \& L. Liu (2010), Seasonal variations and sources of ambient fossil and biogenic-derived carbonaceous aerosols based on ${ }^{14} \mathrm{C}$ measurements in Lhasa, Tibet, Atmospheric Research, 96(4), 553-559, doi:10.1016/j.atmosres. 2010.01.003

Huang, J., Kang, S., Zhang, Q., Guo, J., Chen, P., Zhang, G., \& Tripathee, L. (2013), Atmospheric deposition of trace elements recorded in snow from the Mt. Nyainqentanglha region, southern Tibetan Plateau, Chemosphere, 92(8), 871-881, doi:10.1016/j.chemosphere.2013.02.038

Huo, M. Q., Sato, K., Ohizumi, T., Akimoto, H., \& Takahashi, K. (2016), Characteristics of carbonaceous components in precipitation and atmospheric particle at Japanese sites, Atmospheric Environment, 146, 164-173, doi:10.1016/j.atmosenv.2016.07.017

Ishikawa, Y., Murakami, H., Sekine, T., Yoshihara, K. (1995). Precipitation scavenging studies of radionuclides in air using cosmogenic ${ }^{7}$ Be. Journal of Environmental Radioactivity 26, 19-36

Jacobson, M. Z. (2004), Climate response of fossil fuel and biofuel soot, accounting for soot's feedback to snow and sea ice albedo and emissivity, Journal of Geophysical Research: Atmospheres, 109(D21), n/a-n/a, doi:10.1029/2004jd004945

Jurado, E., Dachs, J., Duarte, C., \& Simó, R. (2008), Atmospheric deposition of organic and black carbon to the global oceans, Atmospheric Environment, 42, 7931-7939, doi:10.1016/j. atm osenv.2008.07.029

Kang, S., Chen, P., Li, C., Liu, B., \& Cong Z. (2016), Atmospheric Aerosol Elements over the Inland Tibetan Plateau: Concentration, Seasonality, and Transport, Aerosol and Air Quality Research, 16(3), 789-800, doi:10.4209/aaqr.2015.05.0307

Kang, S., Q. Zhang, Y. Qian, Z. Ji, C. Li, Z. Cong, Y. Zhang, J. Guo, W. Du, and J. Huang (2019), Linking Atmospheric Pollution to Cryospheric Change in the Third Pole Region: Current Progresses and Future Prospects, National Science Review, nwz031, doi: 10.1093/nsr/nwz031

Kaspari, S. D., Schwikowski, M., Gysel, M., Flanner, M. G., Kang, S., Hou, S., \& Mayewski, P. A. (2011), Recent increase in black carbon concentrations from a Mt. Everest ice core spanning 1860-2000 AD, Geophysical Research Letters, 38(4), n/a-n/a, doi:10.1029/2010g1046096Li, C., Bosch, C., Kang, S., Andersson, A., Chen, P., Zhang, Q., et al. (2016a), Sources of black carbon to the Himalayan-Tibetan Plateau glaciers, Nature communications, 7, 12574, doi: 10.1038/ncomms 12574 
Li, C., Chen, P., Kang, S., Yan, F., Li, X.,Qu, B., \& Sillanpää, M. (2016b), Carbonaceous matter deposition in the high glacial regions of the Tibetan Plateau, Atmospheric Environment, 141, 203-208, doi:10.1016/j.atmosenv.2016.06.064

Li, C., Chen, P., Kang, S., Yan, F., Tripathee, L., Wu, G., et al. (2018a), Fossil Fuel Combustion Emission From South Asia Influences Precipitation Dissolved Organic Carbon Reaching the Remote Tibetan Plateau: Isotopic and Molecular Evidence, Journal of Geophysical Research: Atmospheres, 123(11), 6248-6258, doi:10.1029/2017jd028181

Li, C., Kang, S., Yan, F., (2018b). Importance of Local Black Carbon Emissions to the Fate of Glaciers of the Third Pole. Environmental Science \& Technology, 52, 14027-14028, doi: 10.1021/acs.est.8b06285

Li, C., Kang, S., \& Zhang Q. (2009), Elemental composition of Tibetan Plateau top soils and its effect on evaluating atmospheric pollution transport, Environmental Pollution, 157(8-9), 2261-2265

Li, C., Yan, F., Kang, S., Chen, P., Han, X., Hu, Z., et al. (2017a), Re-evaluating black carbon in the Himalayas and the Tibetan Plateau: concentrations and deposition, Atmospheric Chemistry and Physics, 17(19), 11899-11912, doi:10.5194/acp-17-11899-2017

Li, C., Yan, F., Kang, S., Chen, P., Hu, Z., Gao, S., et al. (2016c), Light absorption characteristics of carbonaceous aerosols in two remote stations of the southern fringe of the Tibetan Plateau, China, Atmospheric Environment, 143, 79-85, doi:10.1016/j.atmosenv.2016. 08.042

Li, C., Yan, F., Kang, S., Chen, P., Hu, Z., Han, X., et al. (2017b), Deposition and light absorption characteristics of precipitation dissolved organic carbon (DOC) at three remote stations in the Himalayas and Tibetan Plateau, China, Science of The Total Environment, 605, 1039-1046, doi:http://dx.doi.org/10.1016/ j.scitotenv. 2017.06. 232

Li, C., Yan, F., Kang, S., Chen, P., Qu, B., Hu, Z., \& Sillanpää, M. (2016d), Concentration, sources, and flux of dissolved organic carbon of precipitation at Lhasa city, the Tibetan Plateau, Environmental Science and Pollution Research, 23(13), 12915-12921, doi: 10.1007/ s11356 016-6455-1

Li, X., Kang, S., He, X., Qu, B., Tripathee, L., Jing, Z., et al. (2017c), Light-absorbing impurities accelerate glacier melt in the Central Tibetan Plateau, The Science of the total environment, 587-588, 482-490, doi:10.1016/ j.scitotenv. 2017.02.169

Liu, B., Cong, Z., Wang, Y., Xin, J., Wan, X., Pan, Y., Liu, Z., et al. (2017), Background aerosol over the Himalayas and Tibetan Plateau: observed characteristics of aerosol mass loading, Atmospheric Chemistry \& Physics, 17(1), 449-463

Liu, B., Kang, S., Sun, J., Zhang, Y., Xu, R., Wang, Y., et al. (2013), Wet precipitation chemistry at a high-altitude site (3,326 m a.s.l.) in the southeastern Tibetan Plateau, Environmental Science and Pollution Research, 20(7), 5013-5027, doi:10.1007/ s11356- 012 - 1379-х

Lüthi, Z. L., Škerlak, B., Kim, S. W., Lauer, A., Mues, A., Rupakheti, M., \& Kang S. (2015), Atmospheric brown clouds reach the Tibetan Plateau by crossing the Himalayas, Atmospheric Chemistry and Physics, 15, 6007-6021, doi:10.5194/acp-15-6007-2015

Ming, J., Cachier, H., Xiao, C., \& Qin, D. (2008), Black carbon record based on a shallow Himalayan ice core and its climatic implications, Atmospheric Chemistry \& Physics, 8, 1343-1352, www.atmos-chem-phys.net/8/1343/2008/ 
Ming, J., Xiao, C., Cachier, H., Qin, D., Qin, X., Li, Z., \& Pu, J. (2009), Black Carbon (BC) in the snow of glaciers in west China and its potential effects on albedos, Atmospheric Research, 92(1), 114-123, doi:10.1016/j.atmosres.2008.09.007

Ming, J., Xiao, C., Du, Z., \& Yang, X. (2013), An overview of black carbon deposition in High Asia glaciers and its impacts on radiation balance, Advances in Water Resources, 55, 80-87, doi:10.1016/j.advwatres.2012.05.015

Ming, J., Xiao, C., Sun, J., Kang, S., \& Bonasoni, P. (2010), Carbonaceous particles in the atmosphere and precipitation of the Nam Co region, central Tibet, Journal of Environmental Sciences, 22(11), 1748-1756

Niu, H., Kang, S., Wang, H., Zhang, R., Lu, X., Qian, Y., Paudyal, R., Wang, S., Shi, X., Yan, X. (2018). Seasonal variation and light absorption property of carbonaceous aerosol in a typical glacier region of the southeastern Tibetan Plateau. Atmospheric Chemistry and Physics 18, 6441-6460

Ogren, J., (1982), Deposition of particulate elemental carbon from the atmosphere, Particulate Carbon. Springer, pp. 379-391

Petzold, A., Ogren, J. A., Fiebig, M., Laj, P., Li, S., Baltensperger, U., et al. (2013), Recommendations for reporting "black carbon" measurements, Atmospheric Chemistry and Physics, 13(16), 8365-8379, doi:10.5194/acp-13-8365-2013

Prado-Fiedler, R. (1990). On the relationship between precipitation amount and wet deposition of nitrate and ammonium. Atmospheric Environment. Part A. General Topics 24, 3061-3065

Qi, L., Li, Q., He, C., Wang, X., \& Huang J. (2017a), Effects of the Wegener-Bergeron-Findeisen process on global black carbon distribution, Atmospheric Chemistry \& Physics, 17, 7459-7479. https://doi.org/10.5194/acp-17-7459-2017

Qi, L., Li, Q., Li, Y., \& He, C. (2017b), Factors controlling black carbon distribution in the Arctic, Atmospheric Chemistry \& Physics, 17(2), 1037-1059

Qian, Y., Yasunari, T. J., Doherty, S. J., Flanner, M. G., Lau, W. K. M., Ming, J., et al. (2015), Light-absorbing particles in snow and ice: Measurement and modeling of climatic and hydrological impact, Advances in Atmospheric Sciences, 32(1), 64-91, doi:10.1007/s00376014-0010-0

Quinn, P., Stohl, A., Arneth, A., Berntsen, T., Burkhart, J., Christensen, J., et al. (2011), The impact of black carbon on Arctic climate, Arctic Monitoring and Assessment Programme, Oslo. 72 pp. ISBN - 978-82-7971-069-1

Ramanathan, V., \& Carmichael, G. (2008), Global and regional climate changes due to black carbon, Nature Geoscience, 1(4), 221-227, doi:10.1038/ngeo156

Ruppel, M. M., Isaksson, I., Ström, J., Beaudon, E., Svensson, J., Pedersen, C. A., \& Korhola, A. (2014), Increase in elemental carbon values between 1970 and 2004 observed in a 300-year ice core from Holtedahlfonna (Svalbard), Atmospheric Chemistry and Physics, 14(20), 1144711460, doi:10.5194/acp-14-11447-2014

Sandnes, H., 1993. Calculated budgets for airborne acidifying components in Europe, 1985, 1987, 1988, 1989, 1990, 1991 and 1992. Meteorological Synthesizing Centre-West, the Norwegian Meteorological Institute.

Seinfeld, J. H., \& Pankow, J. F. (2003), Organic atmospheric particulate material, Annual review of physical chemistry, 54, 121-140, doi:10.1146/annurev.physchem.54.011002.103756 
Sharma, S., Ishizawa, M., Chan, D., Lavoué, D., Andrews, E., Eleftheriadis, K., \& Maksyutov, S. (2013), 16-year simulation of Arctic black carbon: Transport, source contribution, and sensitivity analysis on deposition, Journal of Geophysical Research: Atmospheres, 118(2), 943-964, doi:10.1029/2012jd017774

Textor, C., Schulz, M., Guibert, S., Kinne, S. Balkanski, Y., Bauer, S., et al. (2006), Analysis and quantification of the diversities of aerosol life cycles within AeroCom, Atmospheric Chemistry \& Physics, 5(5), 8331-8420

Tian, L., Masson-Delmotte, V., Stievenard, M., Yao, T., Jouzel, J., 2001. Tibetan Plateau summer monsoon northward extent revealed by measurements of water stable isotopes. Journal of Geophysical Research: Atmospheres 106, 28081-28088

Torres, A., Bond, T. C., Lehmann, C. M. B., Subramanian, R., \& Hadley, O. L. (2013), Measuring Organic Carbon and Black Carbon in Rainwater: Evaluation of Methods, Aerosol Science and Technology, 48(3), 239-250, doi:10.1080/02786826.2013.868596

Tsyro, S., Simpson, D., Tarrasón, L., Klimont, Z., Kupiainen, K., Pio, C., \& Yttri, K. E. (2007), Modeling of elemental carbon over Europe, Journal of Geophysical Research, 112(D23), doi:10.1029/2006jd008164

Wang, Q., Co, J., Han, Y., Tian, J., Zhu, C., Zhang, Y., et al. (2018), Sources and physicochemical characteristics of black carbon aerosol from the southeastern Tibetan Plateau: internal mixing enhances light absorption, Atmospheric Chemistry and Physics, 18(7), 4639-4656, doi:10.5194/acp-18-4639-2018

Wang, Q., Huang., R., Cao, J., Tie, X., Ni, H. Y., Zhou, Y., Han, Y., Hu, T., Zhu, C., Feng, T., Li, N., and J.D. Li (2015), Black carbon aerosol in winter northeastern Qinghai-Tibetan Plateau, China: the source, mixing state and optical property, Atmospheric Chemistry and Physics, 15(22), 13059-13069, doi:10.5194/acp-15-13059-2015

Wang, Q., Jacob, D. J., Spackman, J. R., Perring, A. E., Schwarz, J. P., Moteki, N., et al. (2014), Global budget and radiative forcing of black carbon aerosol: Constraints from pole-to-pole (HIPPO) observations across the Pacific, Journal of Geophysical Research: Atmospheres, 119(1), 195-206, doi:10.1002/2013jd020824

Wu, G., Liu, Y., He, B., Bao, Q., Duan, A., Jin, F.F., 2012. Thermal controls on the Asian summer monsoon. Scientific Report 2, 404

Xu, B., Cao, J., Hansen, J., Yao, T., Joswia, D. R., Wang, N., et al. (2009), Black soot and the survival of Tibetan glaciers, Proceedings of the National Academy of Sciences, 106(52), 22114-22118

Xu, J., Zhang, Q., Shi, J., Ge, X., Xie, C., Wang, J., et al. (2018), Chemical characteristics of submicron particles at the central Tibetan Plateau: insights from aerosol mass spectrometry, Atmospheric Chemistry and Physics, 18(1), 427-443, doi:10.5194/acp-18-427- 2018

Yan, F.,Kang, S., Li, C., Zhang, Y., Qin, X., Li, Y., et al. (2016), Concentration, sources and light absorption characteristics of dissolved organic carbon on a medium-sized valley glacier, northern Tibetan Plateau, The Cryosphere, 10(6), 2611-2621, doi:10.5194/tc-10-2611-2016

Yang, J., Kang, S., Ji, Z., \& Chen, D. (2018), Modeling the Origin of Anthropogenic Black Carbon and Its Climatic Effect Over the Tibetan Plateau and Surrounding Regions, Journal of Geophysical Research: Atmospheres, 123(2), 671-692, doi:10.1002/2017jd027282

Yasunari, T. J., Bonasoni, P., Laj, P., Fujita, K., Vuillermoz, E., Marinoni, A., et al. (2010), Estimated impact of black carbon deposition during pre-monsoon season from Nepal Climate Observatory- 
Pyramid data and snow albedo changes over Himalayan glaciers, Atmospheric Chemistry and Physics, 10(14), 6603-6615, doi:10. 5194/acp-10-6603-2010

Zhan, C., Cao, J., Han, Y., Wang, P., Huang, R., Wei, C., et al. (2015), Spatial patterns, storages and sources of black carbon in soils from the catchment of Qinghai Lake, China. European Journal of Soil Science, 66, 525-534

Zhang, L., Gong, S., Padro, J., Barrie, L. (2001), A size-segregated particle dry deposition scheme for an atmospheric aerosol module. Atmospheric Environment, 35, 549-560Zhang, R., Wang, H., Qian, Y., Rasch, P. J., Easter, R. C., Ma, P. L., et al. (2015b), Quantifying sources, transport, deposition, and radiative forcing of black carbon over the Himalayas and Tibetan Plateau, Atmospheric Chemistry and Physics, 15(11), 6205-6223

Zhang, X., Ming, J., Li, Z., Wang, F., \& Zhang (2017), G., The online measured black carbon aerosol and source orientations in the Nam Co region, Tibet, Environmental science and pollution research international, 24(32), 25021-25033, doi:10.1007/s11356-017-0165-1

Zhang,Y., Cerqueira, M., Salazar, G., Zotter, P., Hueglin, C., Zellweger, C., et al. (2015a), Wet deposition of fossil and non-fossil derived particulate carbon: Insights from radiocarbon measurement, Atmospheric Environment, 115, 257-262, doi:10.1016/j. atmosenv.2015.06.005

Zhao, Z., Cao, J., Shen, Z., Xu, B., Zhu, C., Chen, et al. (2013), Aerosol particles at a high-altitude site on the Southeast Tibetan Plateau, China: Implications for pollution transport from South Asia, Journal of Geophysical Research: Atmospheres, 118(19), 11,360-311,375, doi:10.1002/jgrd.50599

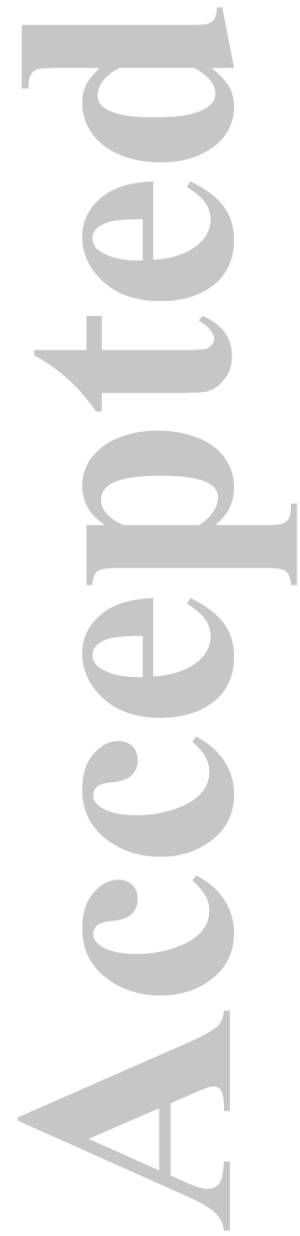


Table 1. WIOC and $\mathrm{BC}$ concentrations and scavenging ratios in precipitation at three study stations in the Himalayas and Tibetan Plateau (HTP) and other study regions in the world

\begin{tabular}{|c|c|c|c|c|c|c|}
\hline Sampling site & Site type & Period & $\begin{array}{l}\text { WIOC (BC) concentration }(\mu \mathrm{g} \\
\left.\qquad \mathrm{L}^{-1}\right)\end{array}$ & $\begin{array}{c}\text { WIOC }(\mathrm{BC}) \text { scavenging } \\
\text { ratio }\left(10^{6}\right)\end{array}$ & Method & Reference \\
\hline Nam Co & HTP & 2015-2017 & $192 \pm 258.6(18.5 \pm 33.7)$ & $0.42(0.24)$ & TOR & This study \\
\hline & HTP & $2015-2016$ & $327 \pm 258(34.3 \pm 35.3)$ & $0.08(0.06)$ & TOR & This study \\
\hline Everest & HTP & 2015-2017 & $248 \pm 210(13.5 \pm 14.5)$ & $0.22(0.09)$ & TOR & This study \\
\hline Nam Co & HTP & 2006 & $476 \pm 565(8 \pm 7)$ & & TOR & 1 \\
\hline Zhadang glacier & НTP & 2013-2014 & $290(37.9)$ & & TOT & 2,3 \\
\hline Demula glacier & НTP & 2013-2014 & $198.5(17.2)$ & & TOT & 2,3 \\
\hline East Rongbuk & HTP & 2013-2014 & $82.9(10.4)$ & & TOT & 2,3 \\
\hline Tokyo, Japan & Urban & 2011-2012 & $657(78.9)$ & $0.81(0.10)$ & TOR & 4 \\
\hline Paris, France & Urban & $1988-1990$ & $851(333)$ & $(0.15)$ & $\begin{array}{c}\text { Two-step thermal } \\
\text { process }\end{array}$ & 5 \\
\hline Sado & Remote & 2011-2012 & $274(26)$ & $1.24(0.08)$ & TOR & 4 \\
\hline Ger & Mountain & 2003-2004 & $205 \pm 266(28 \pm 38)$ & $0.40(0.17)$ & Thermal-optical method & 6 \\
\hline Sonnbick, Austria & Mountain & $2003-2004$ & $145(5.2)$ & $0.63(0.18)$ & Thermal-optical method & 6 \\
\hline Aveiro, Portugal & Rural & 2003-2004 & $98 \pm 56(14 \pm 13)$ & $0.06(0.02)$ & Thermal-optical method & 6 \\
\hline K-Puszta, Hungary & Rural & 2003-2004 & $358(24)$ & $0.57(0.04)$ & Thermal-optical method & 6 \\
\hline Northern Michigan & Rural & 1983-1985 & & $(0.13)$ & Thermal-optical method & 7 \\
\hline
\end{tabular}


Table 2. Deposition rates of WIOC and BC at the three stations and other related sites

\begin{tabular}{|c|c|c|c|c|c|}
\hline Sampling site & Site type & Period & $\begin{array}{c}\text { Annual wet (total) } \\
\text { WIOC deposition rates } \\
\left(\mathrm{mg} \mathrm{m}^{-2} \mathrm{yr}^{-1}\right)\end{array}$ & $\begin{array}{l}\text { Annual wet (total) } \\
\text { BC deposition rates } \\
\quad\left(\mathrm{mg} \mathrm{m}^{-2} \mathrm{yr}^{-1}\right)\end{array}$ & Reference \\
\hline $\mathrm{Nam} \mathrm{Co}$ & HTP & 2015-2017 & $60.2(329.2)$ & $5.8(15.3)$ & This study \\
\hline Lulang & HTP & 2015-2016 & $330(530)$ & $34.6(58.9)$ & This study \\
\hline Everest & HTP & 2015-2017 & $47.0(99.1)$ & $2.6(9.7)$ & This study \\
\hline Zhadang gl & HTP & 2013-2014 & (153.0) & $(20.0)$ & 1,2 \\
\hline Demula glacier & HTP & 2013-2014 & $(167.1)$ & $(14.5)$ & 1,2 \\
\hline East Rongbuk & HTP & 2013-2014 & $(41.5)$ & (5.2) & 1,2 \\
\hline Nam Co Lake core & HTP & 1857-2009 & & (260) & 3 \\
\hline Qinghai Lake core & HTP & 1770-2011 & & $(270-390)$ & 4 \\
\hline WDC06A ice core & West Antarctica & $1850-2000$ & & $\left((16 \pm 2.7)^{*} 10^{-3}\right)$ & 5 \\
\hline DSSW19K ice core & East Antarctic & $1850-2000$ & & $\left((13.5 \pm 2.7)^{*} 10^{-3}\right)$ & 5 \\
\hline Holtedahlfonna ice & Svalbard, Arctic & 1700-2004 & & $(6-26)$ & 6 \\
\hline Tokyo, Japan & Urban & 2011-2012 & 676 & 59.8 & 7 \\
\hline Sado, Japan & Remote & 2011-2012 & 314 & 26.3 & 7 \\
\hline Aveiro, Portugal & Rural & 2003-2004 & 61 & 7.5 & 8 \\
\hline Schauinsland, Germany & Mountain & 2003-2004 & 378 & 38 & 8 \\
\hline
\end{tabular}




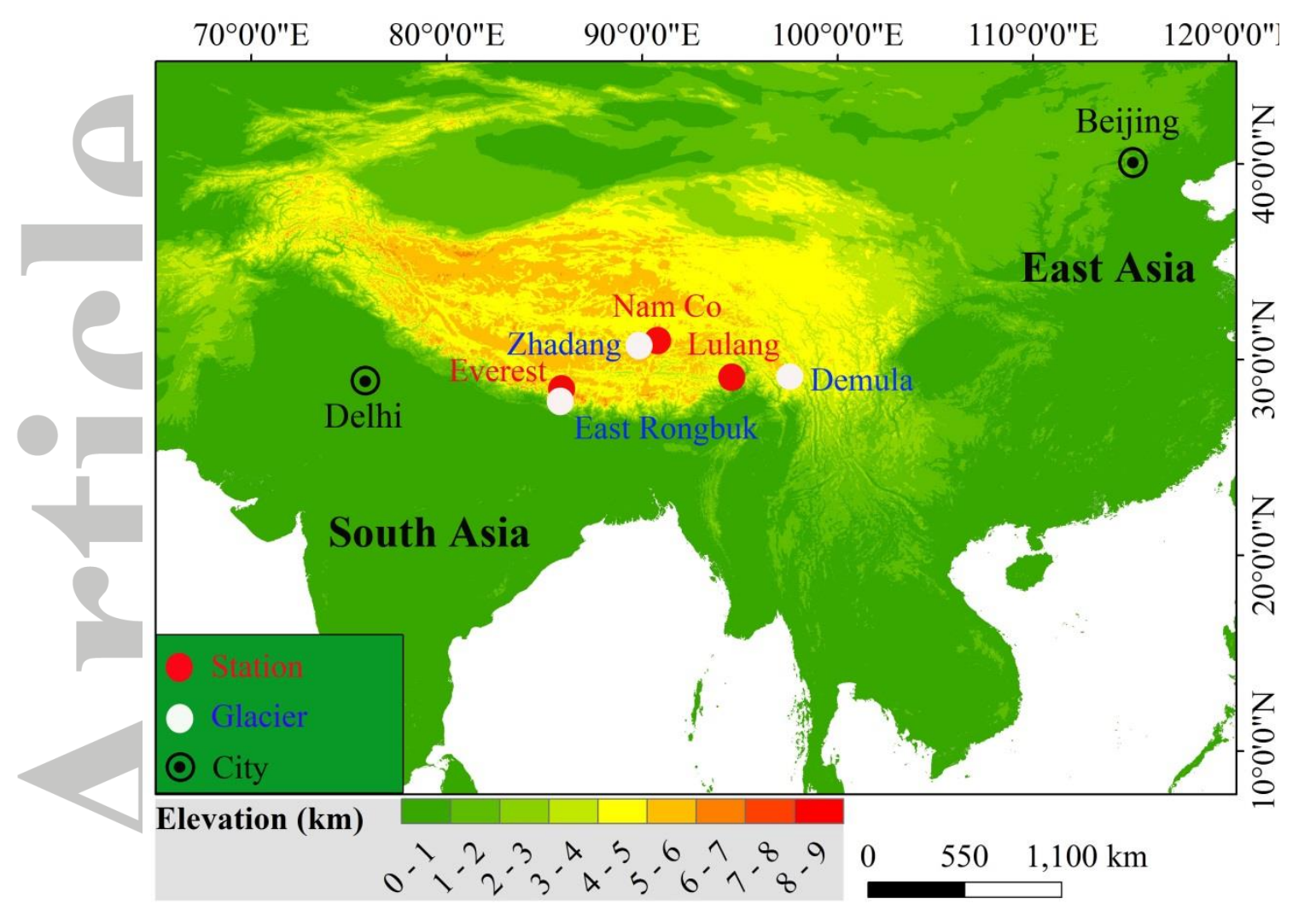

Figure 1. Location map of Nam Co, Lulang, and Everest stations and the nearby glaciers in the Himalayas and Tibetan Plateau.

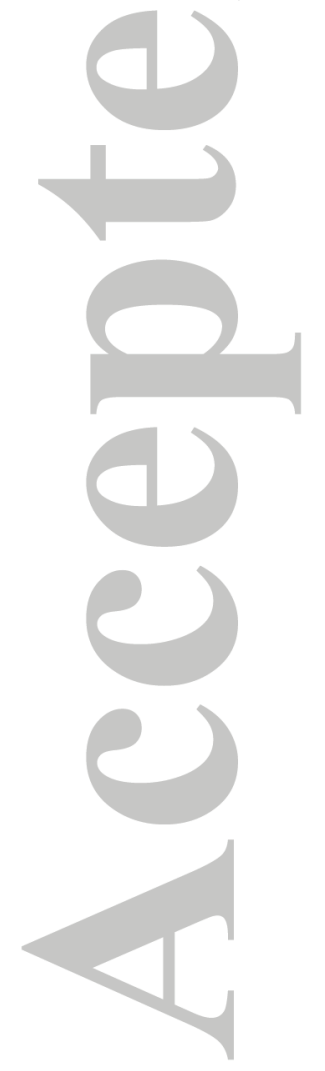

(C) 2019 American Geophysical Union. All rights reserved. 


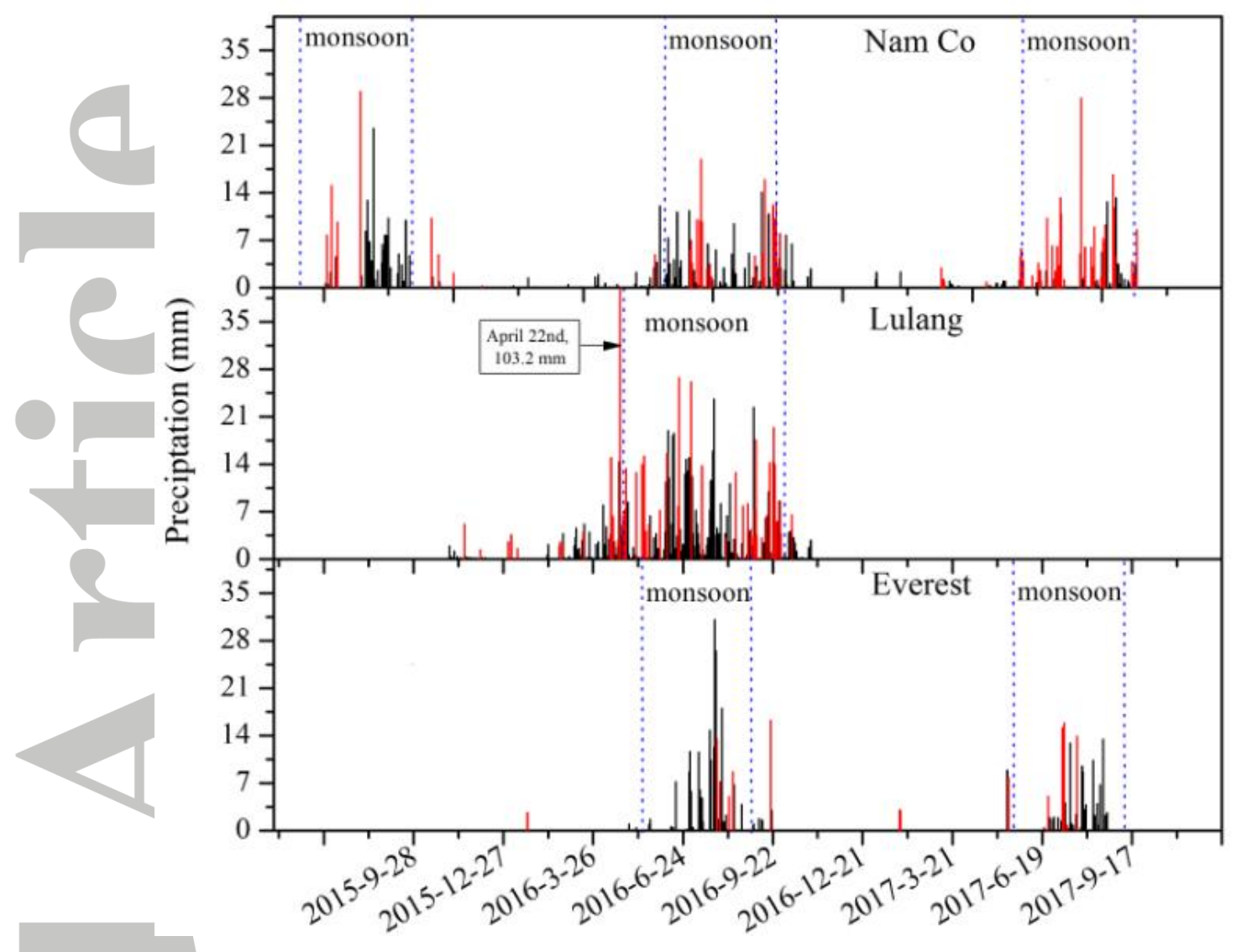

Figure 2. Precipitation amounts at three study stations during the sampling periods. Note: the red and black columns represent the collected and non-collected precipitation events, respectively. Because Lulang Station is situated southeast of the Himalayas and Tibetan Plateau, the monsoon period lasts longer than that at the other two stations (Tian et al., 2001; Wu et al., 2012). 


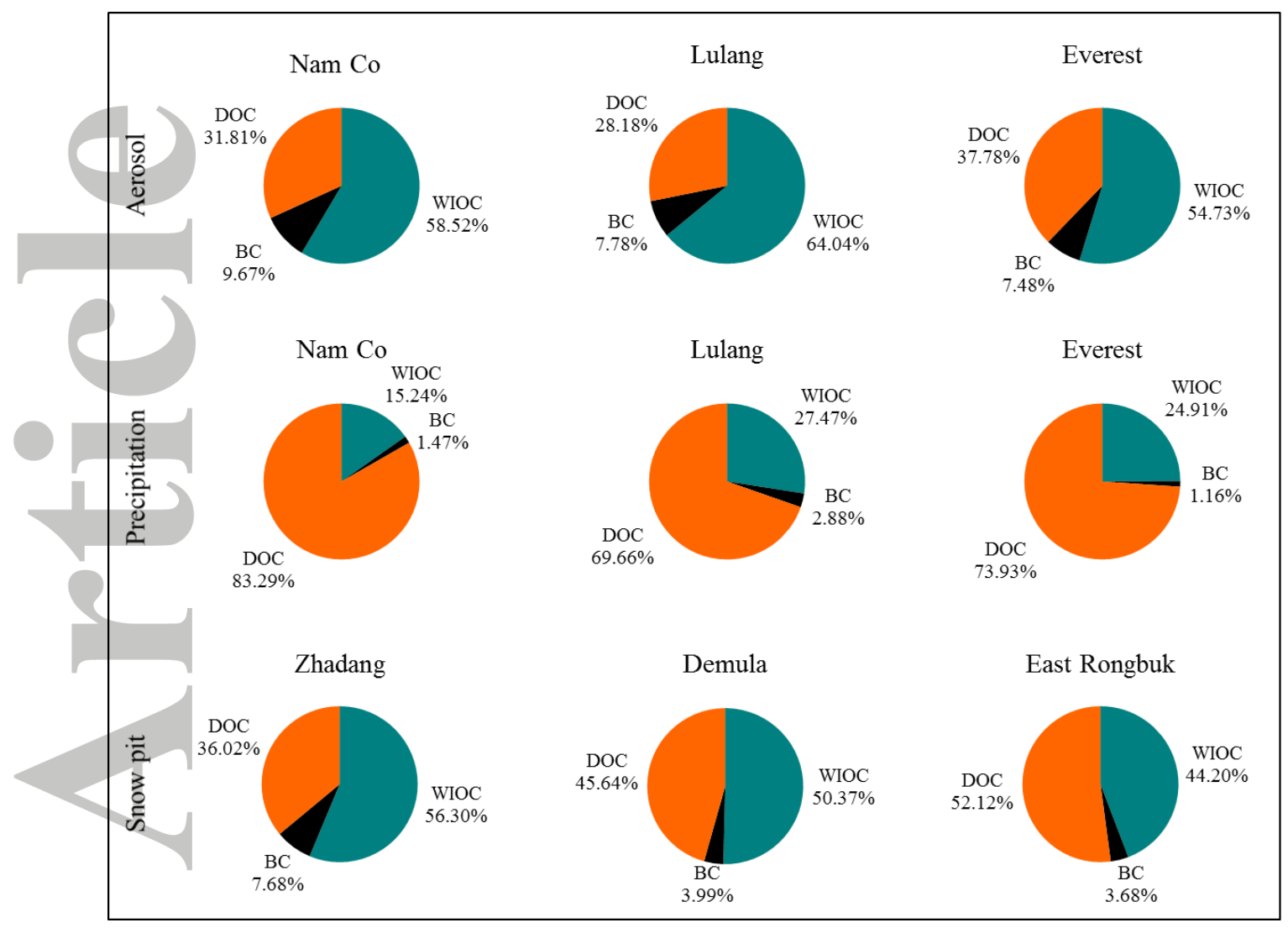

Figure 3. Percentages of $\mathrm{WIOC}, \mathrm{BC}$ and $\mathrm{DOC}$ in the precipitation and aerosols of three stations and the nearby snow pits in the study glacial region of the Himalayas and Tibetan Plateau. Note: the concentrations of WIOC, BC and DOC in the three snow pits were from Li et al., (2016b). The concentrations of WIOC, BC (after considering the influence of carbonate carbon) and DOC in the Everest aerosols were from Cong et al., (2015); the WIOC and BC concentrations in Lulang aerosols were from Zhao et al., (2013); the DOC concentration in the Lulang aerosols was calculated from Zhao et al., (2013) and Li et al., (2016c). 

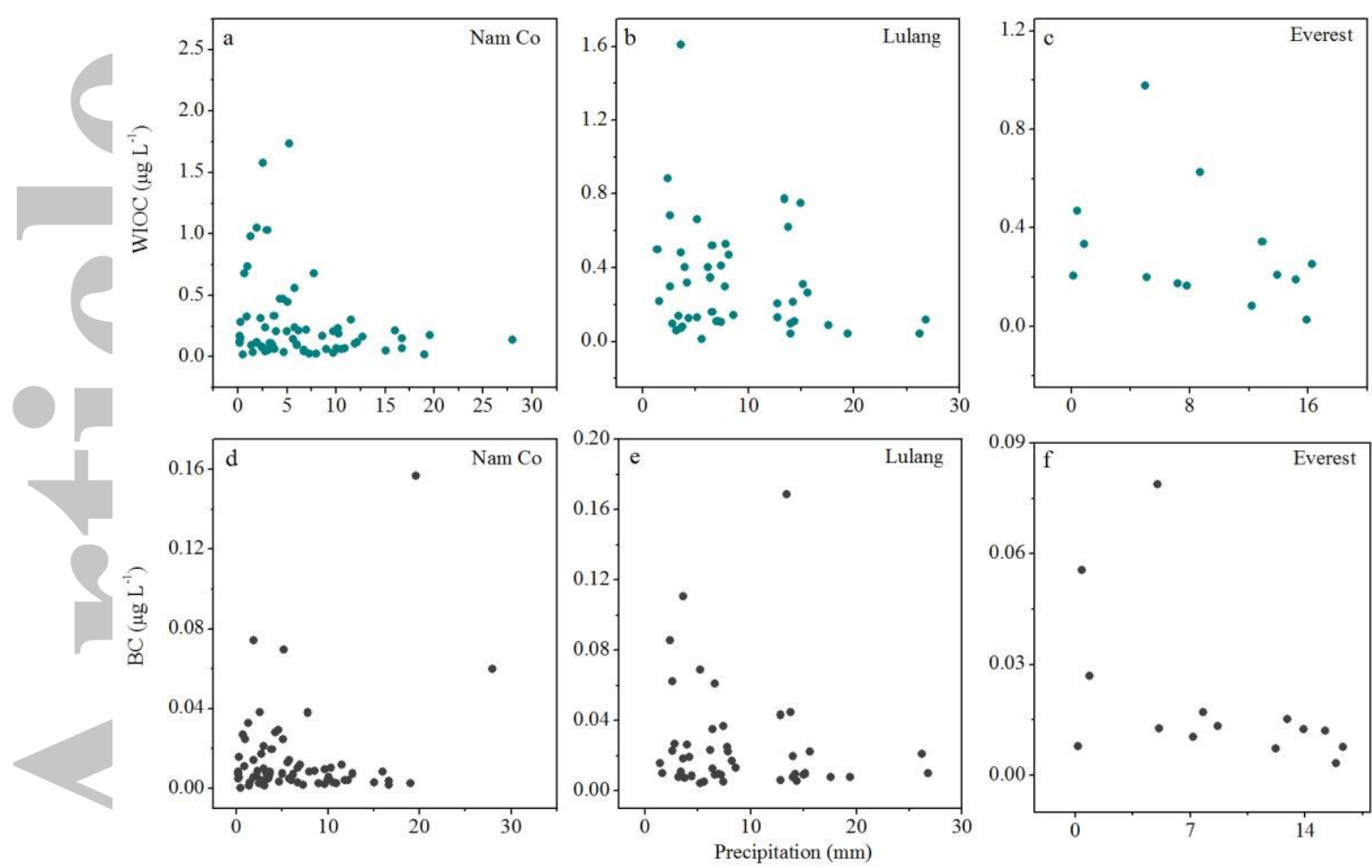

Figure 4. The relationship between WIOC and BC concentrations in precipitation with precipitation amounts at the three study stations.
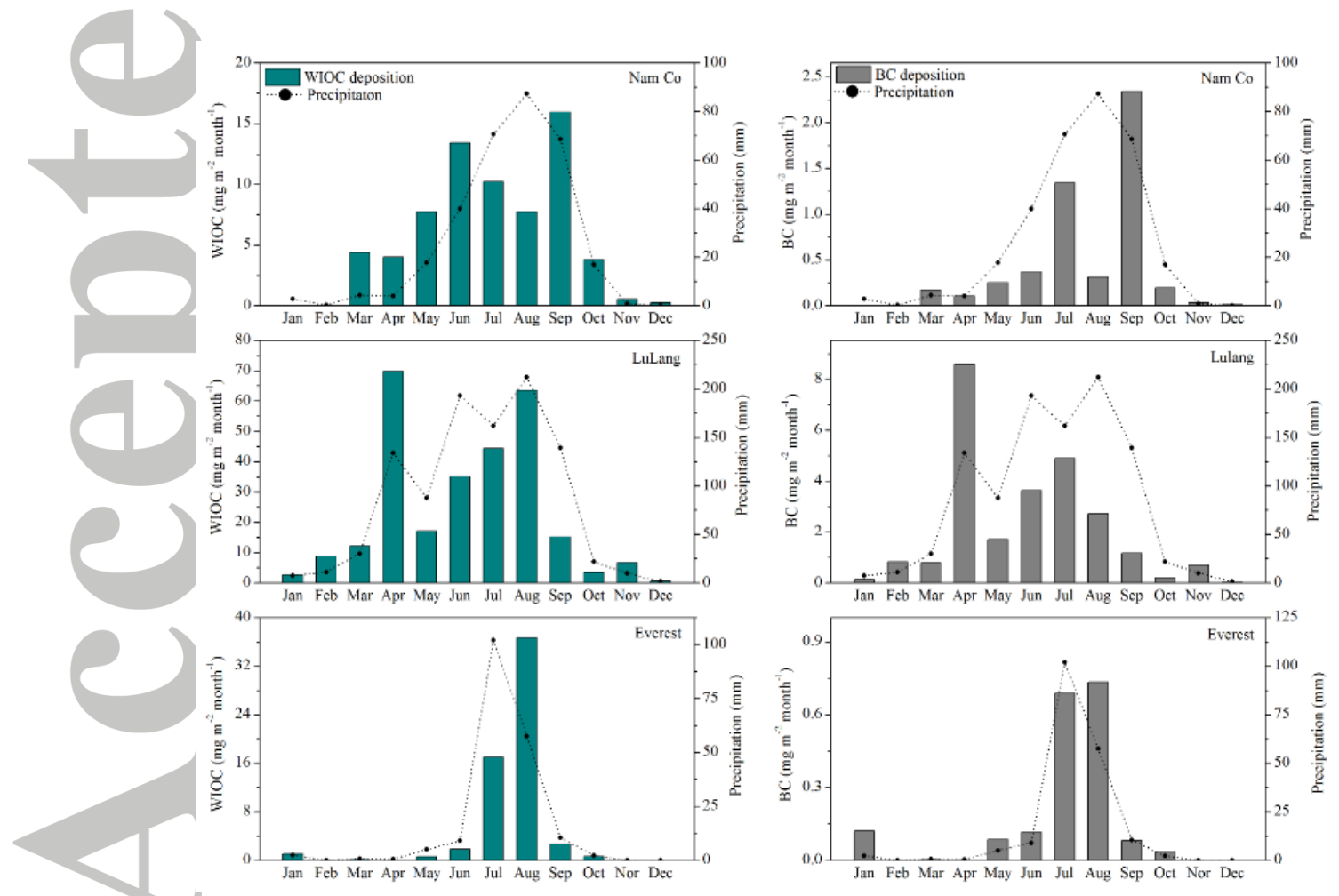

Figure 5. Wet deposition rates of WIOC and BC at the three stations. 


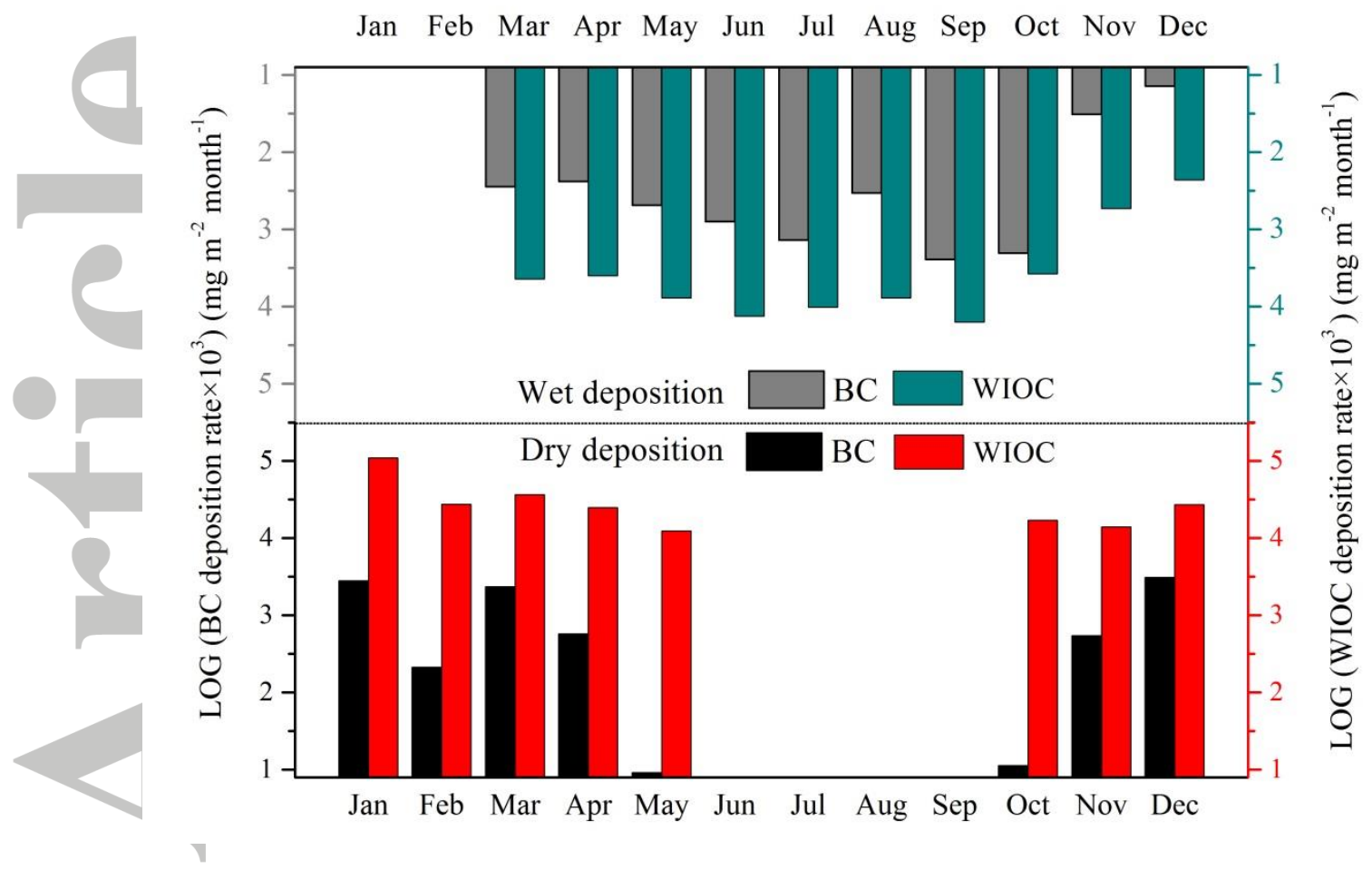

Figure 6. Monthly variation in WIOC and BC dry and wet deposition rates at Nam Co Station. Note: to facilitate comparisons, the wet and dry deposition rates were calculated using a logarithmic algorithm after multiplying by 1000 . 